\title{
Keanekaragaman Tanaman Pangan Kehutanan Pada Lahan Agroforestri Di Desa Haurkuning Kecamatan Nusaherang Kabupaten Kuningan
}

\author{
Dian rudiansah $^{1)}$, Ai Nurlaila ${ }^{2)}$, Ika Karyaningsih ${ }^{3)}$ \\ ${ }^{1}$ Program Studi Kehutanan, Fakultas Kehutanan, Universitas Kuningan \\ email: dian01@gmail.com \\ ${ }^{2}$ Program Studi Kehutanan, Fakultas Kehutanan, Universitas Kuningan \\ email: ai.nurlaila@uniku.ac.id \\ ${ }^{3}$ Program Studi Kehutanan, Fakultas Kehutanan, Universitas Kuningan \\ email: ika.karyaningsih@uniku.ac.id
}

\begin{abstract}
Abstrak.Kebutuhan pangan terus meningkat dari tahun ke tahun dan salah satu upaya dalam meningkatkan produksi pangan adalah dengan mengolah lahan hutan yang berpotensi tanaman pangan dengan sistem agroforestri yang terdapat di Desa Haurkuning. Penelitian ini dilakukan pada bulan Maret hingga Juni 2018 dan bertujuan untuk mengetahui keanekaragaman tanaman pangan kehutanan pada lahan agroforestri dan status budidayanya. Penelitian ini dilakukan dengan metode wawancara kepada setiap petani agroforestri yang memiliki luas> 0,25 ha dengan cara random sampling. Menurut Peraturan Menteri Kehutanan: 35 / Kementerian Kehutanan-II / 2007 di Desa Haurkuning terdapat 19 jenis tanaman pangan yang terdiri dari 5 jenis tanaman sebagai sumber karbohidrat, 13 jenis tanaman penghasil buah dan 2 penghasil minyak lemak. 60\% dari tanaman pangan ini dibudidayakan oleh masyarakat, yang meliputi penyiapan benih, penanaman, pemeliharaan, dan panen.
\end{abstract}

Kata Kunci: Agroforestri; Status Budidaya; Keanekaragaman; Desa Haurkuning

\section{PENDAHULUAN}

Kebutuhan pangan dari tahun ke tahun terus meningkat. Hal ini ditunjukkan dengan masih adanya kegiatan impor untuk memenuhi kebutuhan pangan. Kepala Badan Pusat Statistik (BPS) Suhariyanto mengatakan, nilai impor barang konsumsi sepanjang Januari-Juni 2018 mencapai US\$8,18 miliar, naik $21,64 \%$ secara year on year. Komoditas pangan menjadi penyumbang terbesar kenaikan impor barang konsumsi tersebut. BPS mencatat beras, gula, biji gandum dan meslin, serta garam adalah komoditas dengan volume impor terbesar sepanjang semester I/2018. Demikian pula dari segi nilai, penyumbang impor terbesar adalah beras, gula, kedelai, serta biji gandum dan meslin (Andri, 17 Juli 2018).

Laju pertumbuhan penduduk Indonesia meningkat rata-rata $1,49 \%$ per tahun (BPS, 2010) sejak tahun 2000 sampai 2010. Angka tersebut mengindikasikan besarnya bahan pangan yang harus tersedia yang terus meningkat dari waktu ke waktu. Pada tahun 1960-an, konsumsi beras per kapita rakyat Indonesia sekitar $130 \mathrm{~kg} /$ tahun. Namun, rata-rata konsumsi beras masyarakat Indonesia meningkat menjadi 139,15 $\mathrm{kg} / \mathrm{kapita} / \mathrm{tahun}$ pada kurun waktu 2006-2009.
Nilai ini berada diatas rata-rata konsumsi beras dunia sebesar $60 \mathrm{~kg} / \mathrm{kapita} / \mathrm{tahun}$ (Republika, 2010).

Upaya peningkatan produksi tanaman hutan berpotensi pangan adalah dengan memanfaatkan lahan kehutanan dengan mengembangkan sistem agroforestri. Agroforestri dikembangkan untuk memberi manfaat kepada manusia atau meningkatkan kesejahteran masyarakat. Agroforestri utamanya diharapkan dapat membantu mengoptimalkan hasil suatu bentuk penggunaan lahan secara berkelanjutan guna menjamin dan memperbaiki kebutuhan hidup masyarakat, dan dapat meningkatkan daya dukung ekologi, khususnya di daerah pedesaan. Kebutuhan yang besar jika tidak diimbangi peningkatan produksi pangan, akan menghadapi masalah yang serius.

Tanaman pangan menurut Peraturan Pemerintah Republik Indonesia Nomor 68 Tahun 2002 tentang Ketahanan Pangan (Setneg, 2002) adalah segala sesuatu yang berasal dari sumber hayati dan air, baik yang diolah maupun tidak diolah yang diperuntukkan sebagai makanan atau minuman bagi konsumsi manusia, termasuk bahan tambahan pangan, bahan baku pangan, dan bahan lain yang digunakan dalam proses penyiapan, pengolahan, 
dan/atau pembuatan makanan atau minuman. Menurut Kamus Besar Bahasa Indonesia/KBBI (2008) tumbuhan pangan diartikan sebagai sesuatu yang tumbuh, hidup, berbatang, berakar, berdaun, dan dapat dimakan atau dikonsumsi oleh manusia (apabila dikonsumsi hewan disebut pakan). Sedangkan Moeljopawiro dan Manwan (1992) menyatakan dalam mendefinisikan tanaman pangan tak terlepas dari jenis tanaman pangan atau tumbuhan pangan, jenis tanaman pangan ini secara umum dapat dikelompokkan menjadi tiga, yaitu sebagai berikut;

1. omoditas utama, yaitu padi, jagung, kedelai, kacang tanah, kacang hijau, talas, ubi dan sagu.

2. Komoditas potensial, yaitu sorgum (gandrung), kacang tunggak, kacang gude, lena, talas, ubi dan sagu.

3. Komoditas introduksi, yaitu jawuwut, gandum dan kacang biduk.

Hasil hutan bukan kayu (HHBK) atau sering juga disebut hasil hutan non kayu (HHNK) merupakan semua benda biologis termasuk jasa lingkungan yang berasal dari hutan atau tegakan hutan, kecuali produk berupa kayu. Definisi HHBK menurut UU Nomer 41 tahun 1999 hasil hutan bukan kayu terdiri dari benda-benda hayati yang berasal dari flora dan fauna. Selain itu termasuk juga jasa air, udara, dan manfaat tidak langsung dari hutan. Sedangkan menurut Departemen Kehutanan (Permenhut: 35/MENHUT-II/2007) HHBK merupakan hasil hutan baik nabati dan hewani beserta produk turunan dan budidayanya kecuali kayu.

Agroforestri merupakan suatu sistem pengelolaan tanaman hutan (perennial) yang dikombinasikan dengan pertanian atau disebut juga sistem wanatani. Sebenarnya banyak definisi mengenai agroforestry, yang satu sama lain tidak berbeda secara substansi. Banyak definisi dari agroforestry yang sering digunakan dalam dunia pengetahuan. International Council for Research in Agroforestry (ICRAF) mendefinisikan agroforestry sebagai suatu sistem pengelolaan lahan yang berazaskan kelestarian, untuk meningkatkan hasil lahan secara keseluruhan, melalui kombinasi produksi (termasuk tanaman pohon-pohonan) dan tanaman hutan dan atau hewan secara bersamaan atau berurutan pada unit lahan yang sama, dan menerapkan cara-cara pengelolaan yang sesuai dengan kebudayaan penduduk setempat". (King dan Chandler (1978) dalam Hairiah (2003)).

Secara lebih rinci tujuan agroforestry atau tumpangsari di kawasan hutan (Perum Perhutani, 1990 dalam Adiputranto, 1995) adalah sebagai berikut:

1. Membantu meningkatkan penyediaan pangan

2. Membantu memperluas lapangan kerja

3. Meningkatkan pendapatan dan kesejahteraan masyarakat sekitar hutan

4. Meningkatkan keberhasilan tanaman hutan

Sedangakan keuntungan/manfaat dari intensifikasi tumpangsari menurut Soekartiko (1980) dalam Adiputranto (1995) adalah:

1. Meningkatkan produksi pangan, pendapatan petani, kesempatan kerja dan meningkatnya kualitas gizi masyarakat sehingga tercapai kesejahteraan petani sekitar hutan

2. Meningkatnya pengetahuan dan keterampilan petani sehingga diharapkan dapat dikembangkan system intensifikasi pertanian pada tanah-tanah kering di pedesaan yang berarti meningkatnya produktifitas tanah pertanian kering (tegalan)

3. Meningkatnya kesadaran masyarakat akan fungsi-fungsi hutan yang diharapka dapat mengurangi tekanan terhadap gangguan hutan.

\section{METODE PENELITIAN}

Penelitian ini dilaksanakan di Desa Haurkuning Kecamatan Nusaherang Kabupaten Kuningan. pada bulan Maret sampai Juni 2018. Alat dan bahan yang digunakan dalam penelitian ini diantaranya:

1. Panduan wawancara untuk mengumpulkan data primer maupun sekunder.

2. Laporan-laporan hasil penelitian, jurnaljurnal, peraturan-peraturan dan berbagai pustaka penunjang sebagai sumber data sekunder untuk melengkapi pengamatan langsung di lapangan.

3. Kamera untuk dokumentasi dan visualisasi objek penelitian. 


\section{Teknik Pengumpulan Data}

Pengumpulan data primer dilakukan dengan observasi dan wawancara secara purposive sampling dan simple random sampling pada kelompok tani di Desa Haurkuning. Total responden adalah 44 orang. Data sekunder diperoleh kantor desa setempat yang meliputi keadan umum lokasi penelitian yang meliputi letak dan keadaan fisik lingkungan dan keadaan social ekonomi masyarakat serta literatur pustaka yang mendukung teori penelitian.

\section{Analis Data}

Data yang diperoleh dari hasil wawancara dan observasi kemudian dianalisis secara deskriptif dalam bentuk tabulasi dan grafik untuk mendapatkan gambaran mengenai karakteristik masyarakat penggarap hutan rakyat/agroforestri Desa Haurkuning.

Analisis vegetasi merupakan suatu cara untuk mempelajari komposisi jenis dan bentuk atau struktur vegetasi yang meliputi tegakan hutan dan tumbuhan bawah. Kriteria yang digunakan untuk menentukan tingkat pertumbuhan adalah sebagai berikut :

- $20 \mathrm{~m}$ x $20 \mathrm{~m}$ untuk pohon

- $\quad 10 \mathrm{~m} \times 10 \mathrm{~m}$ untuk tiang

- $\quad 5 \mathrm{mx} 5 \mathrm{~m}$ untuk pancang

- $\quad 2 \mathrm{mx} 2 \mathrm{~m}$ untuk semai

Data yang dikumpulkan untuk tingkat pohon dan tiang adalah jenis, jumlah individu setiap jenis, diameter batang setinggi dada $(130 \mathrm{~cm})$, tinggi total dan tinggi bebas cabang. Sedangkan data yang dikumpulkan untuk pertumbuhan tingkat semai dan pancang hanyalah jenis dan jumlah individu setiap jenis yang ditemukan. Jumlah plot yang digunakan adalah 44 plot. menggunakan indeks shanon wiener (H'). Rumus yang digunakan adalah

$$
\mathrm{H}^{\prime}=-\sum_{i=1}^{S}\left[\left(\frac{n i}{N}\right) \ln \left(\frac{n i}{N}\right)\right]
$$

$$
\begin{aligned}
& \mathrm{H}^{\prime}=\text { Indeks Keragaman Shannon-Wiener } \\
& \mathrm{S}=\text { Jumlah spesies } \\
& \text { ni = Jumlah individu spesies-i } \\
& \mathrm{N}=\text { Total jumlah individu semua spesies }
\end{aligned}
$$

Analisis untuk mengetahui kompsisi tumbuhan dilakukan dengan mencari angka indeks penting untuk mengetahui jenis tanaman yang dominan. Nilai keanekaragaman tanaman dilakukan dengan Asrianny et al. (2008) menyatakan bahwa kriteria nilai Indeks Keanekaragaman Shanon-Wiener (H') adalah $\mathrm{H}^{\prime}<1$ dikategorikan rendah, $\mathrm{H}^{\prime}$ bernilai 1-3 termasuk kategori sedang, nilai $\mathrm{H}^{\prime}>3$ katagori tinggi Sedangkan nilai kemerataan tumbuhan dilakukan dengan menggunakan indeks kemerataan spesies (evenness) dengan rumus yang digunakan yaitu

$$
E=\frac{H^{\prime}}{\ln S}
$$

dengan

$H^{\prime}=$ Indeks keanekaragaman Shannon-Wiener

$\mathrm{S}=$ Jumlah spesies

$\mathrm{E}=$ Indeks kemerataan spesies (evenness).

\section{HASIL DAN PEMBAHASAN Keanekaragaman Tanaman Pangan}

Berdasarkan hasil analisis vegetasi di wilayah agroforestri di Desa Haurkuning terdapat 16 jenis tumbuhan mulai dari tingkat semai,pancang, tiang dan pohon. Jenis tumbuhan yang mempunyai Indeks Nilai Penting (INP) yang mendominasi pada tingkat semai adalah mahoni dengan INP $112 \%$. Pada tingkat pancang INP didominasi oleh kopi dengan INP 96\%, pada tingkat tiang didominasi oleh cengkeh dengan INP $159 \%$. Sedangkan pada tingkat pohon Indeks Nilai Penting didominasi oleh mahoni dengan INP $106 \%$. 
Wanaraksa Vol. 12 No. 2 November 2018

Tabel 1 Nilai INP tertinggi pada berbagai tingkat pertumbuhan di wilayah agroforestri Desa Haurkuning

\begin{tabular}{|c|c|c|c|c|}
\hline Tingkatan Tanaman & No. & Nama Jenis & Nama Ilmiah & $\operatorname{INP}(\%)$ \\
\hline \multirow[t]{5}{*}{ Semai } & 1 & Mahoni & Swietenia macrophylla & 112 \\
\hline & 2 & Cengkeh & Syzigium aromaticum & 30 \\
\hline & 3 & Kopi & Coffea robusta & 27 \\
\hline & 4 & Pete & Parkia speciosa & 19 \\
\hline & 5 & Afrika & Maesopsis eminii & 6 \\
\hline \multirow[t]{5}{*}{ Pancang } & 1 & Kopi & Coffea robusta & 96 \\
\hline & 2 & Cengkeh & Syzigium aromaticum & 88 \\
\hline & 3 & Tisuk & Hibiscus macrophyllus & 10 \\
\hline & 4 & Afrika & Maesopsis eminii & 3 \\
\hline & 5 & Nangka & Artocarpus heterophyllus & 2 \\
\hline \multirow[t]{5}{*}{ Tiang } & 1 & Cengkeh & Syzigium aromaticum & 158 \\
\hline & 2 & Mahoni & Swietenia macrophylla & 90 \\
\hline & 3 & Nangka & Artocarpus heterophyllus & 21 \\
\hline & 4 & Melinjo & Gnetum gnemon & 11 \\
\hline & 5 & Jengkol & Phytthecelobium sp. & 6 \\
\hline \multirow[t]{5}{*}{ Pohon } & 1 & Mahoni & Swietenia macrophylla & 106 \\
\hline & 2 & Cengkeh & Syzigium aromaticum & 88 \\
\hline & 3 & Pete & Parkia speciosa & 29 \\
\hline & 4 & Kelapa & Cocos nucipera & 15 \\
\hline & 5 & Nangka & Artocarpus heterophyllus & 14 \\
\hline
\end{tabular}

Sedangkan untuk tanaman pangan yang mendominasi pada tingkat semai adalah pete, tingkat pancang nangka, tingkat tiang nangka, melinjo, dan jengkol, serta tingkat pohon pete dan nangka. Pete, nangka, melinjo, jengkol termasuk tanaman pangan kehutanan yang termasuk 5 besar tanaman yang mendominasi setiap tingkat pertumbuhan. Hal ini karena masyarakat lebih memilih tanaman kelompok buah-buahan yang penanamannya bisa berdampingan dengan tanaman kayu atau tanaman kehutanan sebagai komoditi utama. Jenis tanaman lainnya mempunyai INP yang relaif kecil sehingga tidak mendominasi lahan garapan yang bererti tanaman tersebut hanya sebagai tanaman sela (bukan tanaman pokok) yang tumbuh secar liar ataupun budidaya.

Tingkat keanekaragaman tanaman pangan pada berbagai tingkat pertumbuhan di Desa Haurkuning berdasarkan indeks shanon-wiener termasuk kedalam kategori rendah. Pada tingkat semai nilai keanekaragaman tertinggi adalah tanaman pete dengan nilai $H^{\prime} 0,23$, pada tingkat pancang dan tiang $H^{\prime}$ tertinggi pada tanaman nangka sebesar 0,04 dan 0,14 dan pada tingkat pohon $H^{\prime}$ tertinggi pada tanaman pete sebesar 0,17 (tabel 5.2). Magurran (2004) dalam Nahlunnisa et al, 2015 menyatakan bahwa nilai kemerataan yang mendekati satu menunjukkan bahwa suatu komunitas semakin merata penyebarannya, sedangkan jika nilainya mendekati nol maka penyebarannya semakin tidak merata. Berdasarkan perhitungan Evenes (E) tanaman pangan di Desa Haurkuning memiliki kemerataan yang rendah, hal ini menunjukan bahwa penyeberan tanaman pangan di Desa Haurkuning tidak merata. Meskipun indeks keanekaragaman dan kemerataan tanaman pangan terbilang rendah, namun tanaman pangan di Desa Haurkuning memiliki potensi untuk membantu meningkatkan ekonomi masyarakat. 
Tabel 2 Indeks keanekaragaman dan kemerataan tanaman pangan

\begin{tabular}{|c|c|c|c|c|}
\hline $\begin{array}{c}\text { Tingkat } \\
\text { pertumbuhan }\end{array}$ & Nama jenis & Nama ilmiah & $\mathrm{H}^{\prime}$ & E \\
\hline \multirow[t]{2}{*}{ Semai } & Pala & Myristica fragran & 0.23 & 0.00 \\
\hline & Pete & Parkia spiciosa & 0.01 & 0 \\
\hline pancang & Nangka & Artocarpus heterophyllus & 0.04 & 0 \\
\hline \multirow[t]{5}{*}{ Tiang } & Jengkol & Phyttecelobium sp. & 0.06 & 0.01 \\
\hline & Mangga & Mangifera indica & 0.04 & 0 \\
\hline & Melinjo & Gnetum gnemon & 0.12 & 0.01 \\
\hline & Nangka & Artocarpus heterophyllus & 0.14 & 0.02 \\
\hline & Pala & Muristtica fragran & 0.07 & 0.01 \\
\hline \multirow[t]{8}{*}{ Pohon } & Durian & Durio zibethinus & 0.03 & 0 \\
\hline & Jengkol & Phyttecelobium sp. & 0.08 & 0 \\
\hline & Mangga & Mangifera indica & 0.03 & 0 \\
\hline & Matoa & Pometia pinnata & 0.04 & 0 \\
\hline & Melinjo & Gnetum gnemon & 0.09 & 0.01 \\
\hline & Nangka & Artocarpus heterophyllus & 0.12 & 0.01 \\
\hline & Pete & Parkia spiciosa & 0.17 & 0.01 \\
\hline & Sukun & Artocarpus communis & 0.03 & 0 \\
\hline
\end{tabular}

\section{a. Kelompok Tanaman sebagai Sumber karbohidrat}

Jenis tanaman pangan sebagai sumber karbohidrat yang ditemukan di Desa Haurkuning sesuai Permenhut No. 35/2007 terdapat 5 jenis, yaitu aren, bambu, gadung, jamur dan suweg. Bambu tua sering dimanfaatkan sebagai bahan bangunan, peralatan rumah tangga dan dijual secara langsung. Tanaman sebagai sumber karbohidrat yang lain seperti gadung, suweg, aren dan jamur masih belum dan jarang dimanfaatkan oleh masyarakat khususnya responden, padahal jenis-jenis tersebut memiliki potensi yang cukup besar untuk dimanfaatkan. Seperti gadung dapat dimanfaatkan sebagai tepung gadung atau keripik gadung, aren dapat dimanfaatkan sebagai gula aren, kolang-kaling dan sebagainya. Hal ini karena masyarakat Desa Haurkuning masih memanfaatkan beras sebagai sumber karbohidrat utama. 
Tabel 3 kelompok tanaman sebagai karbohidrat/pati

\begin{tabular}{|c|c|c|c|c|c|c|c|}
\hline \multirow[b]{2}{*}{ No } & \multirow[b]{2}{*}{$\begin{array}{l}\text { Jenis } \\
\text { Pangan }\end{array}$} & \multirow[b]{2}{*}{ Nama Ilmiah } & \multirow[b]{2}{*}{ Habitus } & \multicolumn{2}{|c|}{ Produk } & \multicolumn{2}{|c|}{$\begin{array}{c}\text { Status } \\
\text { Budidaya }\end{array}$} \\
\hline & & & & $\begin{array}{l}\text { Berdasarkan } \\
\text { Permenhut } \\
\text { P.35/2007 }\end{array}$ & $\begin{array}{l}\text { Pemanfaatan } \\
\text { di Masyarakat }\end{array}$ & Liar & Budidaya \\
\hline 1 & Aren & Arenga pinnata & Palem & $\begin{array}{l}\text { Tepung aren, } \\
\text { gula aren }\end{array}$ & & $\sqrt{ }$ & \\
\hline 2 & Bambu & Dendrocalamus asper & bambu/rumput & Rebung & Rebung & $\sqrt{ }$ & \\
\hline 3 & Gadung & Dioscorea hispida & Merambat & $\begin{array}{l}\text { Tepung } \\
\text { gadung }\end{array}$ & $\begin{array}{l}\text { Umbi, keripik } \\
\text { gadung }\end{array}$ & $\sqrt{ }$ & \\
\hline 4 & Jamur & $\begin{array}{l}\text { Agaricus spp; Pleurotus } \\
\text { spp; Lentinus spp; } \\
\text { Ganoderma spp }\end{array}$ & Jamur & Jamur & Jamur & $\sqrt{ }$ & \\
\hline 5 & Suweg & $\begin{array}{l}\text { Amorphophallus } \\
\text { campanulatus }\end{array}$ & Perdu & tepung suweg & Umbi & $\sqrt{ }$ & \\
\hline
\end{tabular}

\section{b. Kelompok Tanaman sebagai Penghasil buah}

Jenis tanaman penghasil buah-buahan sebagian besar adalah tanaman budidaya yang ditanam langsung oleh masyarakat (pemilik lahan) sebab tanaman penghasil buah ini dapat memberikan manfaat langsung bagi pemilik dengan menjual hasil buah kepada tengkulak atau ke pasar. Durian, jemgkol, sirsak, mangga, matoa, nangka, pala dan pete adalah jenis-jenis buah-buahan yang langsung dijual ke pengepul atau ke pasar degan harga yang bervariasi. Sedangkan untuk mellinjo petani biasanya mengolahnya terlebih dahulu. Buah melinjo yang muda dan daunnya seringkali dijual ke pasar/ke warung sebagai campuran sayur asem, buah melinjo yang tua diolah menjadi keripik emping melinjo bahkan kullit ari buah melinjo tua seringkali dijual sebagai bahan sayur ataupun digoreng dijadikan camilan. a. Kelompok Tanaman sebagai Penghasil Minyak Lemak

Berdasarkan tumbuhan penghasilnya, terdapat 19 jenis tumbuhan, yaitu: balam, bintaro, buah merah, croton, kelor, kemiri, kenari, ketapang, ketiau, lena/wijen, macadamia, mimba, nyamplung, nyatoh,picung, saga pohon, seminai, suntai dan tengkawang (Ary Widiyanto et al, 2013). Dari 19 jenis tanaman tersebut 2 (dua) diantaranya ada di Desa Haurkuning yaitu kelor dan kemiri. Masyarakat Desa Haurkuning baru memanfaatkan kemiri hanya sebatas untuk bumbu masak sedangkan kelor belum dimanfaatakn. 
Tabel 4 kelompok tanaman penghasil buah

\begin{tabular}{|c|c|c|c|c|c|c|c|}
\hline \multirow[b]{2}{*}{ No } & \multirow[b]{2}{*}{ Jenis Pangan } & \multirow[b]{2}{*}{ Nama Ilmiah } & \multirow[b]{2}{*}{ Habitus } & \multicolumn{2}{|c|}{ Produk } & \multicolumn{2}{|c|}{ Status Budidaya } \\
\hline & & & & $\begin{array}{c}\text { Berdasarkan } \\
\text { Permenhut } \\
\text { P.35/2007 }\end{array}$ & $\begin{array}{l}\text { Pemanfaatan di } \\
\text { Masyarakat }\end{array}$ & Liar & Budidaya \\
\hline 1 & Aren & Arenga pinnata & Palem & Kolang-kaling & & $\sqrt{ }$ & \\
\hline 2 & Durian & Durio zibethinus & Pohon & Buah durian & Buah durian & & $\sqrt{ }$ \\
\hline 3 & Jengkol & Phythecelobium sp. & Pohon & Buah jengkol & Buah jengkl & & $\sqrt{ }$ \\
\hline 4 & $\begin{array}{l}\text { Mangga } \\
\text { hutan }\end{array}$ & Mangifera indica & Pohon & Buah manga & Buah manga & $\sqrt{ }$ & $\sqrt{ }$ \\
\hline 5 & Matoa & Pometia pinnata & Pohon & Buah matoa & buah matoa & & $\sqrt{ }$ \\
\hline 6 & Melinjo & Gnetum gnemon & Pohon & Buah melinjo & $\begin{array}{l}\text { Buah melinjo, } \\
\text { keripik emping }\end{array}$ & & $\sqrt{ }$ \\
\hline 7 & Mengkudu & Morinda citrfolia & Pohon & Buah mengkudu & Buah mengkudu & & $\sqrt{ }$ \\
\hline 8 & Nangka & $\begin{array}{l}\text { Arthocarpus } \\
\text { heterophylus }\end{array}$ & Pohon & Buah nangka & Buah nangka & & $\sqrt{ }$ \\
\hline 9 & Pala & Myristica fragran & Pohon & Buah Pala & Buah pala & & $\sqrt{ }$ \\
\hline 10 & Petai & Parkia speciosa & Pohon & Buah Petai & Buah petai & & $\sqrt{ }$ \\
\hline 11 & Rambutan & $\begin{array}{l}\text { Nephelium } \\
\text { lapaceum }\end{array}$ & Pohon & Buah rambutan & Buah Rambutan & & $\sqrt{ }$ \\
\hline 12 & Sukun & $\begin{array}{l}\text { Artocarpus } \\
\text { communis. }\end{array}$ & Pohon & Buah sukun & Buah Sukun & & $\sqrt{ }$ \\
\hline 13 & Sirsak & Annona muricata & Pohon & Buah sirsak & $\begin{array}{l}\text { Buah sirsak, } \\
\text { obat diare }\end{array}$ & & $\sqrt{ }$ \\
\hline
\end{tabular}

Table 5 kelompok tanaman penghasil minyak lemak

\begin{tabular}{cccccccc}
\hline & & & \multicolumn{3}{c}{ Produk } & Status Budidaya \\
No & Jenis & Nama Ilmiah & Habitus & $\begin{array}{c}\text { Berdasarkan } \\
\text { Permenhut } \\
\text { P.35/2007 }\end{array}$ & $\begin{array}{c}\text { Pemanfaatan di } \\
\text { Masyarakat }\end{array}$ & Liar & Budidaya \\
\hline 1 & Kemiri & Aleurites moluccana & Pohon & Minyak kemiri & buah kemiri & $\sqrt{ }$ & $\sqrt{ }$ \\
2 & Kelor & Molinga oleifera & Pohon & Minyak kelor & Daun & $\sqrt{ }$ & $\sqrt{ }$ \\
\hline
\end{tabular}

Hasil penelitian Dwiaprianto (2016) di Kecamatan Nanggung, Kabupaten Bogor menunjukkan masyarakat memanfaatkan tanaman pangan sebanyak 23 jenis. Masyarakat Baduy memanfaatkan 240 spesies tanaman pangan yang berasal dari area budidaya dan hutan alam di sekitar Baduy (Hidayati, 2013).

\section{Status Budidaya Tanaman Pangan Kehutanan}

Tanaman pangan yang terdapat di Desa Haurkuning menurut status budidayanya termasuk ke dalam tanaman yang dibudidayakan dan tanaman liar. Sebagian besar tanaman di Desa Haurkuning merupakan tanaman hasil budidaya sebasar $60 \%$ dan $40 \%$ merupakan tanaman liar atau belum dibudidayakan masyarakat. 


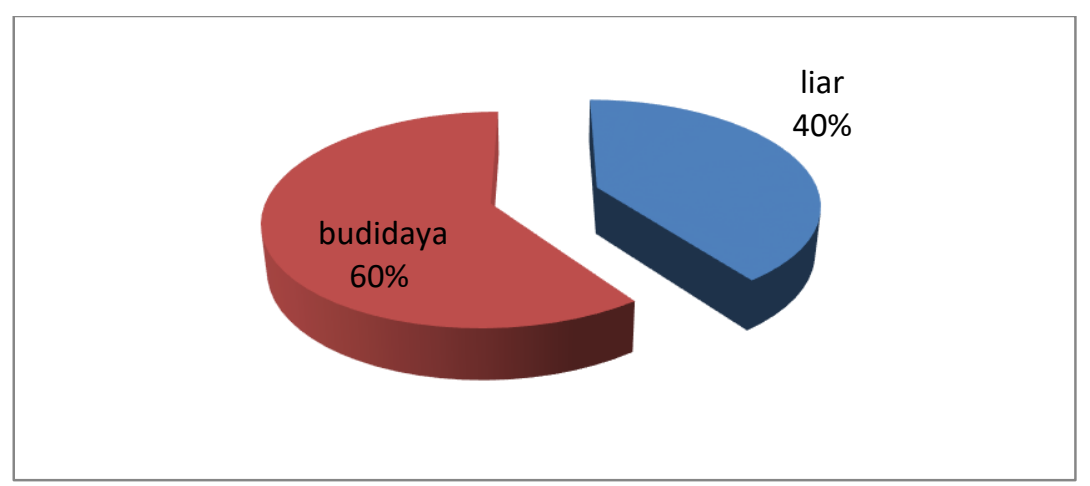

Gambar 1 Persentase tanaman budidaya dan tanaman liar

Tanaman pangan yang dibudidayakan oleh masyarakat adalah tanaman yang sering dikonsumsi. Teknik budidaya tanaman tersebut meliputi persiapan benih dan penanaman, pemeliharaan dan pemanenan.

\section{SIMPULA N}

Keanekaragaman berdasarkan Permenhut: 35/MENHUT-II/2007 termasuk kategori rendah.

\section{DAFTAR PUSTAKA}

Achmad B, Soleh M, Undang S, Dani SR. 2004. Kajian Tata Niaga Kayu Rakyat di Kabupaten Kuningan. Makalah Seminar Ekspose Terpadu Hasil-Hasil Penelitian. Yogyakarta (ID): Badan Litbang Kehutanan.

Apriyanto, D., Hardjanto. Hero, Y.. Peningkatan Peran Hutan Rakyat Dalam Mendukung Ketahanan Pangan Dan Penanggulangan Kemiskinan (Studi Kasus Di Kecamatan Nanggung, Kabupaten Bogor). Jurnal Silvikultur Tropika. 7(3):165-173.

Adiputranto, H.. 1995. Peranan Kegiatan Insus Tumpangsari Perhutanan Sosial terhadap Tingkat Pendapatan Petani di Resort Pemangkuan Hutan Wilangan, BKPH Wilangan Utara, KPH Saradan. Fakultas Kehutanan UGM, Yogyakarta.

Andri, DP. Y., Semester 1/2018, Impor Pangan Indonesia Membengkak. Retrieved December 32018 from https://ekonomi.bisnis.com/read/20180717/ 12/817413/semester-i2018-impor-panganindonesia-membengkak.

Asrianny, Marian, Oka NP. 2008. Keanekaragaman dan kelimpahan jenis berdasarkan Indeks Shanon-wiener, terdiri dari 5 jenis tanaman sebagai penghasil karbohidrat/pati, 13 jenis buah-buahan dan 2 jenis tanaman sebagai penghasil minyak lemak. Status budidaya tanaman pangan pada lahan agroforestri di Haurkuning sebanyak $60 \%$ merupakan tanaman budidaya dan $40 \%$ tanaman liar.

liana (tumbuhan memanjat) pada Hutan Alam di Hutan Pendidikan Universitas Hasanuddin. Jurnal Perennial. 5(1): 23-30. Aswatini, Noveria M dan Fitranita. 2008. Konsumsi Sayur dan Buah di Masyarakat dalam Konteks Pemenuhan Gizi Seimbang. Jurnal Kependudukan Indonesia, Vol. III, No. 2, 2008.

Basrin F, Nasser A. 2012. Studi Pemanfaatan Buah Sukun Sebagai Bahan Tepung dan Aplikasinya dalam Pembuatan Roti Tawar. Retrieved September 17, 2018, from, www.

isjd.pdii.lipi.go.id/admin/jurnal/42125260_ 0216-7530.pdf

Bendang S. 2012. Mewujudkan Kedaulatan Pangan. Retrieved September 15, 2018, from www.spi.or.id

De Foresta, 2000. Ketika Kebun Berupa Hutan: Agroforest Khas Indonesia, Sebuah Subangan Masyarakat. ICRAF. Bogor

De Foresta, H. and G. Michon. 1997. The Agroforest Alternative to Imperata Grassland: When Smallholder Agliculture and Forestry Reach Sustainabilty. Agroforestry Systems 36: 105-120. 
[Dephut] Departemen Kehutanan. 2007b. Peraturan Menteri Kehutanan Nomor 35 tahun 2007 tentang Hasil Hutan Bukan Kayu. Jakarta: Dephut.

[Dephut] Departemen Kehutanan. 1999. Undang-Undang Nomor 41 tahun 1999 tentang Kehutanan.

Dinas Pertanian Kabupaten Kuningan. 2018. Data Hutan Rakyat. https://distan.kuningankab.go.id/direktori/d ata-hutan-rakyat.

Dwiprabowo, H. Effendi, R. Hakim, I. dan Bangsawan, I. 2011. Kontribusi Kawasan Hutan Dalam Menunjang Ketahanan Pangan : Studi Kasus Provinsi Jawa Barat. E-journal. Analisis Kebijakan Kehutanan: 8-1.

Hairiah K., Widianto, dan Sunaryo. 2003. Sistem Agroforestri Di Indonesia. Bogor

Hairiah, K., M.A., Sardjono, dan S. Sabarnurdin. 2003. Pengantar Agroforestri. World Agroforestry Centre (ICRAF). Bogor

Hidayati S. 2013. Analisis Penerapan Pengetahuan Etnobatani Masyarakat Baduy dalam Ketahanan Pangan [Tesis]. Bogor (ID): Institut Pertanian Bogor. M.A., Sardjono, Djogo T., H.S., Arifin dan Wijayanto N. 2003. Klasifikasi dan Pola Kombinasi Komponen Agroforestri. Bogor

[KBBI] Kamus Besar Bahasa Indonesia. 2008. Jakarta (ID) : Balai Pustaka.

Nahlunnisa, N., Prasetyo, L.B., Zuhud, E.A.M. 2015. Penyebaran Spasial Keanekaragaman Tumbuhan Pangan Dan Obat Di Kampung Nyungcung, Desa Malasari, Kecamatan Nanggung, Bogor. Media Konservasi. 20:187-196.

Manullang M, Yohani V. 1995. Ekstraksi dan Analisis Polisakarida Buah Sukun (Artocarpus altilis). Bul. Tek. Dan Industri Pangan, Vol. VI No.3 Th. 1995.

Mayrowani H, Ashari. 2011. Pengembangan Agroforestri Untuk Mendukung Ketahanan Pangan dan Pemberdayaan Petani Sekitar Hutan. Pusat Sosial Ekonomi dan Kebijakan Pertanian. Bogor.

Moeljopawiro, S. dan Manwan I. 1992. Pengembangan Pemanfaatan Tanaman Pangan di Indonesia. Prosiding Seminar dan Lokakarya Nasional Etnobotani. Departemen Pendidikan dan Kebudayaan,
Departemen Pertanian dan Lembaga Ilmu Pengetahuan Indonesia : Bogor.

Padmowijoto, S. 2006. Integrasi Legume dengan Tanaman Pangan dan Ternak Kambing dalam Mratani Sistem. Prospect Tahun 2 Nomor 2, Pebruari 2006. Hal 1-4. (PDF) Agroforestry dan Peranannya dalam Mempertahankan Fungsi Hidrologi dan Konservasi. Retrieved July 04, 2018, from, https://www.researchgate.net/publication/3 00142098_Agroforestry_dan_Peranannya_ dalam_Mempertahankan_Fungsi_Hidrologi dan_Konservasi

Perhutani. 2002a. Petunjuk Pengelolaan Sumber Daya Hutan Bersama Masyarakat di unit I Jawa Tengah. Semarang: Biro Pembinaan Sumber Daya Hutan.

Puspitojati, T. 2011a. Agroforestry forest estate: whole rotation of social forestry. makalah poster disampaikan pada Seminar INAFOR Tanggal 5-7 Desember 2011 di Bogor.

Puspitawati H, Fahmi SA. 2008. Analisis Pembagian Peran gender Pada Keluarga Petani (Gender Role Analysis on Farmer Families). Publikasi Artikel Ilmiah Vol. 1 No.2, Agustus 2008.

Rahayu S. 2013. Pemanfaatan Tumbuhan Pangan Dan Obat Oleh Masyarakat Kampung Sinarwangi Di Sekitar Hutan Gunung Salak Kabupaten Bogor [skripsi]. Bogor (ID): Institut Pertanian Bogor.

Setneg Republik Indonesia. (1996). Peraturan Pemerintah Republik Indonesia Nomor 68 Tahun 2002 tentang Ketahanan Pangan.

Simalango W. Komoditas Sumber Karbohidrat. Retrieved Desember 26, 2018, from, http://www.academia.edu/27057960/Komo ditas_sumber_karbohidrat.

Soemitro, P.W. 2001. Peranan Hijauan Legume dan Ternak dalam Pertanian Berkelanjutan. Pidato Pengukuhan Sebagai Guru Besar Fakultas Peternakan $\mathrm{UGM}(P D F)$ Agroforestry dan Peranannya dalam Mempertahankan Fungsi Hidrologi dan Konservasi. Retrieved July 04, 2018, from, https://www.researchgate.net/publication/3 00142098_Agroforestry_dan_Peranannya_ dalam_Mempertahankan_Fungsi_Hidrologi _dan_Konservasi 
Soerianegara, I., dan Idrawan, A., 1978. Ekologi Hutan Indonesia. Institut Pertanian Bogor, Bogor.

Sudrajat S, Hardjanto dan Sundawati L. 2016. Partisipasi Petani Dalam Pengelolaan Hutan Rakyat Lestari:Kasus Di Desa Cikeusal Dan Desa Kananga Kabupaten Kuningan. Jurnal Silvikultur Tropika 07(1), 2016: 817. Bogor

Sunarti S, Rugayah dan Djarwaningsih T. 2007. Tumbuhan Berpotensi Bahan Pangan di Daerah Cagar Alam Tangale. Jurnal Biodiversitas 8(2), 2007 : 88-91. Bogor.

Widiyanto A., Siarudin M. 2013. Minyak Lemak, Salah Satu Potensi Hasil Hutan
Bukan Kayu Yang Perlu Dikembangkan. Balai Penelitian Teknologi Agroforestri. Ciamis. Retrieved Desember 26, 2018, from, https://www.Researchgate.Net/Publication/ 299981427_Minyak_Lemak_Salah_Satu_P otensi_Hasil_Hutan_Bukan_Kayu_Yang_P erlu_Dikembangkan.

Widianto, Hairiah K., Suharjito D., dan M.A., Sardjono. 2003. Fungsi dan Peran Agroforestri. Bogor.

Yonida, A.D. 2018. Jenis-Jenis Tanaman Pangan. Retrieved Oktober 15, 2018, from, https://farming.id/jenis-jenis-tanamanpangan/. 